\author{
Stanislav Kotenko \\ Sumy State University, Ukraine \\ iD https://orcid.org/0000-0001-8684-0163, \\ email:s.kotenko@management.sumdu.edu.ua \\ Iryna Heiets \\ Ph.D., Associate Professor, RMIT University, Australia \\ https://orcid.org/0000-0003-1267-3790 \\ email:iryna.heiets@rmit.edu.au \\ Dina Yacout \\ Ph.D., The Chartered Institute of Marketing, Egypt \\ https://orcid.org/0000-0002-1691-0370, \\ email:drdinay@windowslive.com
}

Correspondence author: s.kotenko@management.sumdu.edu.ua

\title{
ORGANIZATIONAL COMPETITIVENESS: A SYSTEMATIC LITERATURE REVIEW
}

Abstract. One of the basic economic laws that reflect the patterns of economic phenomena is the law of competition. According to it, in a market economy, those business entities with certain competitive advantages operate and develop successfully. Within the competitive market, organizations are forced to increase their competitiveness, forming certain competitive advantages in the appropriate space-time conditions. Globalization and integration trends make more stringent and complex requirements for various enterprises, leading to increased competition in national and international markets. The multifactorial dependence of organizational competitiveness makes it possible to form new ways to increase the level of this indicator. Endogenous and exogenous factors, in turn, create functional links between different sectors of the economy. This paper presents a bibliometric analysis of the concept of "Organizational competitiveness" using numerous software tools to identify links between factors of organizational competitiveness, its source, and antecedents. The methods used in the study include initial keyword search, data analysis and refinement, and clustering. Harzing's Publish or Perish tool is used for initial investigation, BibExcel, VOSviewer, and MS Excel - for data analysis and refinement. The article uses data from the three most significant databases of scientific publications: Google Scholar, Web of Science, and Scopus. Searching and comparing information taken from several sources allows for a comprehensive analysis of the literature and understanding of the principles of bibliometric maps of publications. In the framework of this study, the authors formed and analyzed cluster groups of concepts, the principles of their grouping, developed scientific approaches to clustering key terms in several databases. The relevance of this study lies in its impact on the process of forming conceptual clusters. With the help of the proposed scientific approaches, it is possible to explain the dependencies in the cluster distribution of individual definitions, their relationship with each other, the degree of belonging to a particular factor of organizational competitiveness.

Keywords: analysis, bibliometric, organizational competitiveness, factors, clustering, publications, visualization.

Introduction. In the existence of any organization and business, there comes a time when it is necessary to assess the overall competitiveness level. It could be due to entering foreign markets or the desire to reorient the business. The procedure for determining the competitiveness level of the organization begins with an assessment of impact factors. Such factors, depending on the sphere of influence, can be endogenous and exogenous. Endogenous (internal) factors in the analysis of organizational competitiveness relate to the processes, systems, human capital, structure, efficiency, and organizational practices of each organization. Endogenous factors of enterprises and organizations interact with each other in order to increase productivity and form a stable competitive advantage.

Cite as: Kotenko, S., Heiets, I., \& Yacout, D. (2021). Organizational competitiveness: a systematic literature review. Marketing and Management of Innovations, 3, 175-187. http://doi.org/10.21272/mmi.2021.3-14 
It is important to take into account exogenous (external) factors based on the fact that organizations are part of industries and operate in different environments. Even if competitiveness is determined at the level of one organization, it continues to be an important component of the state economic policy and every business or industry. Exogenous factors can affect an organization's competitive position by forming and reshaping the external resources and opportunities that, if developed, may help obtain competitive advantages, increasing organizational competitiveness. In the process of bibliometric analysis, publications are studied, which describe various methods of assessing organizational competitiveness and the factors that influence it. In addition, the bibliometric analysis aims to investigate the relationships within the conceptual apparatus. This analysis is designed to determine the factors that influence the key concepts and the nature of organizational competitiveness.

The purpose of this study is to conduct a bibliometric analysis; comparison of statistical data on the number of publications, their impact under the key term "Organizational Competitiveness"; to develop clusters of different scientific approaches that identify organizational competitiveness and its components.

Literature Review. Organizational competitiveness is the focus of many studies across the world. Over the past ten years, the number of citations of works in this sphere has increased several times. The most cited works on this topic according to the three most famous bibliometric databases of publications (Google Scholar, Scopus, Web of Science) are described in Table 1.

Table 1. The most cited works on the key term "Organizational Competitiveness" according to bibliometric databases of scientific publications Google Scholar, Scopus, Web of Science (2010-2020)

\begin{tabular}{|c|c|c|c|c|c|c|}
\hline \multirow{2}{*}{ Authors } & \multicolumn{3}{|c|}{ Number of citations } & \multirow{2}{*}{ Title } & \multirow{2}{*}{ Year } & \multirow{2}{*}{ Journal } \\
\hline & Scholar & Scopus & Wos & & & \\
\hline 1 & 2 & 3 & 4 & 5 & 6 & 7 \\
\hline $\begin{array}{l}\text { E. Fraj, } \\
\text { J. Matute, } \\
\text { I. Melero } \\
\text { (Fraj et al., } \\
\text { 2015) }\end{array}$ & 301 & - & 126 & $\begin{array}{l}\text { Environmental strategies and } \\
\text { organizational competitiveness in } \\
\text { the hotel industry: The role of } \\
\text { learning and innovation as } \\
\text { determinants of environmental } \\
\text { success }\end{array}$ & 2015 & $\begin{array}{l}\text { Tourism } \\
\text { Management }\end{array}$ \\
\hline $\begin{array}{l}\text { N. } \\
\text { Subramanian, } \\
\text { A. } \\
\text { Gunasekaran } \\
\text { (Subramanian } \\
\text { et al., 2015) }\end{array}$ & 113 & - & - & $\begin{array}{l}\text { Cleaner supply-chain } \\
\text { management practices for } \\
\text { twenty-first-century } \\
\text { organizational competitiveness: } \\
\text { Practice-performance framework } \\
\text { and research propositions }\end{array}$ & 2015 & $\begin{array}{l}\text { International } \\
\text { Journal of } \\
\text { Production } \\
\text { Economics }\end{array}$ \\
\hline $\begin{array}{l}\text { J.G. Vargas- } \\
\text { Hernández, } \\
\text { M.R. Noruzi } \\
\text { (Vargas- } \\
\text { Hernández et } \\
\text { al., 2010) }\end{array}$ & 98 & - & - & $\begin{array}{l}\text { How intellectual capital and } \\
\text { learning organization can foster } \\
\text { organizational competitiveness? }\end{array}$ & 2010 & $\begin{array}{l}\text { International } \\
\text { Journal of } \\
\text { Production } \\
\text { Economics }\end{array}$ \\
\hline $\begin{array}{l}\text { N. Kabir, } \\
\text { E. Carayannis } \\
\text { (Kabir et al., } \\
\text { 2013) }\end{array}$ & 74 & - & - & $\begin{array}{l}\text { Big data, tacit knowledge and } \\
\text { organizational competitiveness }\end{array}$ & 2013 & $\begin{array}{l}\text { 10th } \\
\text { International } \\
\text { Conference } \\
\text { on Intellectual } \\
\text { Capital, } \\
\text { Knowledge } \\
\text { Management }\end{array}$ \\
\hline
\end{tabular}


Continued Table 1

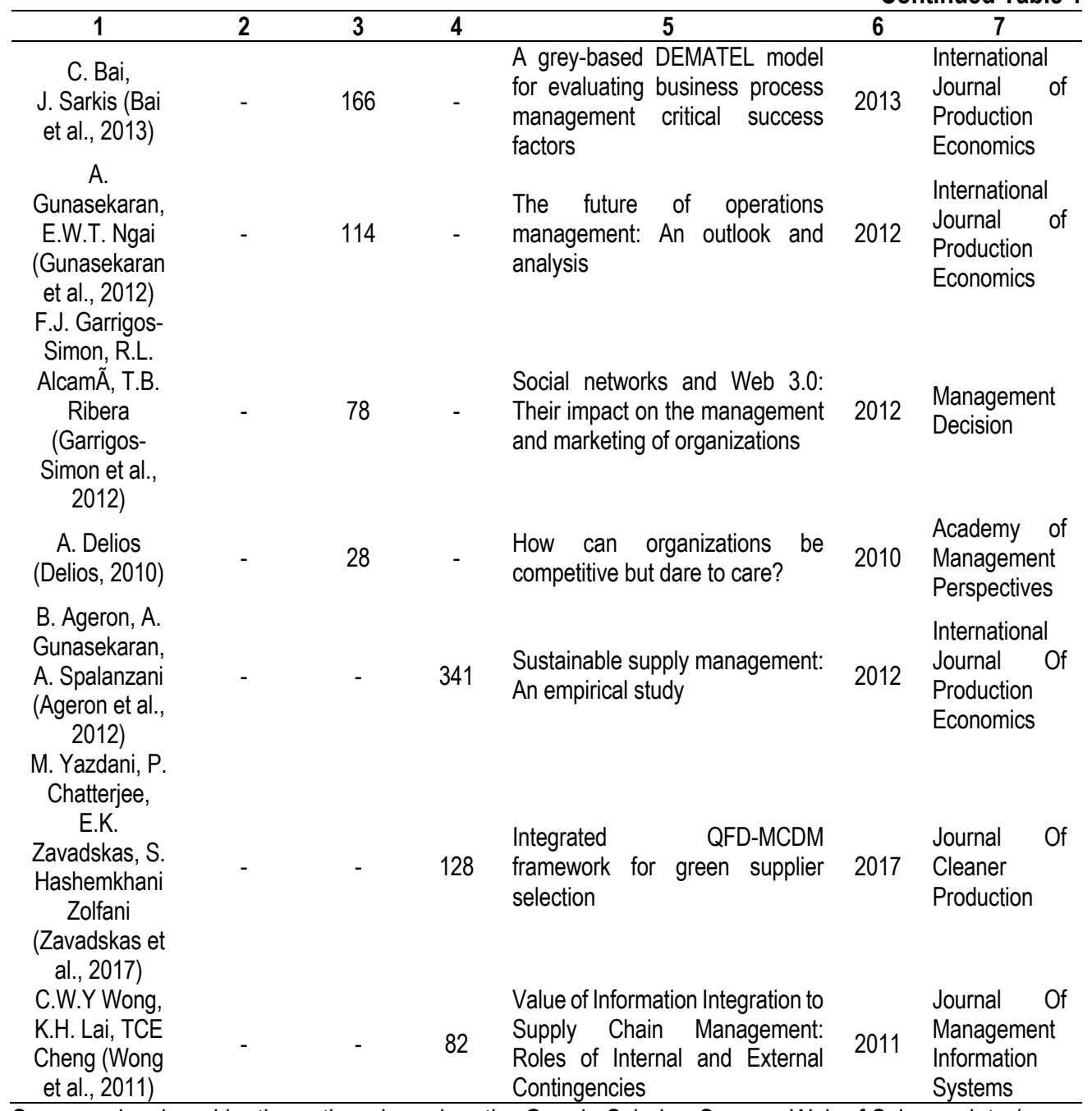

Sources: developed by the authors based on the Google Scholar, Scopus, Web of Science data (access date 27.09.2020)

One of the most cited articles in the Scholar and Web of Science databases belongs to Frai, Matute, and Melero (Fraj et al., 2015). In their article "Environmental strategies and organizational competitiveness in the hotel industry: The role of learning and innovation as determinants of environmental success", the author explores the links between environmental strategies, organizational capabilities, and competitiveness. The authors note that the focus on learning and innovation is conceived not only as a driver for environmental policy but also as a determinant of the competitiveness of organizations. Spanish researchers have proposed a three-factor model of the impact on the organizational competitiveness of the hotel sector. Graphical representation of the model is presented in fig.1. 


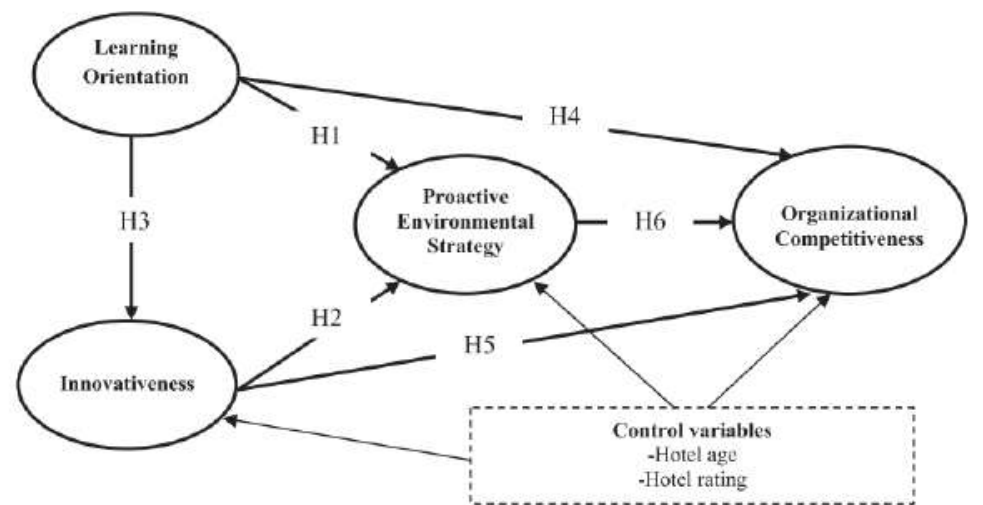

Figure 1. Graphic representation of model by E. Frai, J. Matute, I. Melero

Sources: Fraj et al., 2015.

In Figure 1, the proposed model combines factors influencing organizational competitiveness was presented. The authors tested the proposed model using a sample of 232 Spanish hotels. The study results show that the focus on learning has a positive effect on innovation in the field of hospitality; it means that innovation and proactive environmental strategy directly affect the organizational competitiveness. The value of this study is manifested in the development of a model that includes non-traditional factors of competitiveness of the organization. The emphasis on ecology, culture and innovation reflects the current trend in finding sources to increase organizational competitiveness in all spheres of economic life. The relevance of this topic is confirmed by the high citation rate of this scientific work.

The study by Bai and Sarkis on the DEMATEL methodology and its impact on the business process management system and organizational competitiveness is noteworthy (Bai et al., 2013). The Test and Evaluation Laboratory (DEMATEL) methodology was first used by scientists Fontela and Gabus in 1976. The methodology took into account the opinions of experts in many global complex problems in the scientific, political, and economic spheres. As part of their work, Bai and Sarkis found that business process management can accelerate organizational processes, reduce resources required, increase productivity and efficiency, and increase the competitiveness of organizations. Researchers have shown that the DEMATEL methodology can not only be used as a way to address interdependencies within a set of individual criteria for the functioning of the organization but can also provide more valuable information for management decisions. The DEMATEL methodology plays an important role in improving the business process management system, especially when organizations exist and operate in complex competitive environment. The most cited work on "organizational competitiveness" in the Web of Science database is an article by Ageron, Gunasekaran, Spalanzani entitled "Sustainable supply management: An empirical study" (Ageron et al., 2012). This article discusses the sustainable development of supply management because it is critical to an organization's competitiveness. Scientists have tried to create a theoretical basis and then substantiate it with empirical research using the ideas and practices of individual French companies. The authors concluded that many companies have difficulty managing the sustainable development of their business, even if they agree that their activities are highly dependent on the responsibility to partners and stakeholders. The paper emphasizes on the significance of the combination of internal and external factors within a sustainable development framework, noting that this is a necessary condition and determining factor of organizational competitiveness.

There should be mentioned the overview of the concept of competitiveness accomplished earlier (Shvindina, 2020), as long as studies on the problems of its measurement (Kotenko \& Shvindina, 2018, 
2020; Kotenko et al., 2021a), or its link with regional capabilities to form innovations (Kotenko et al., 2021b).

Methodology and research methods. The following toolkit was used to conduct a direct bibliometric analysis of the key terms "Organizational competitiveness":

- Harzing's Publish or Perish.

- BibExcel.

- VOSviewer.

- MS Excel.

Harzing's Publish or Perish and BibExcel can be used to generate source data from sources such as Google Scholar, Web of Science, and Scopus. VOSviewer is used to obtain graphical and visual results. MS Excel is used to refine data and identify patterns. Data from three databases of publications were used in bibliometric analysis of literature sources: Google Scholar, Scopus and Web of Science. These three databases are important for scientists around the world, and are an indicator of the publishing activity of the latter. The study aims to identify the features of clustering the terms of the key concept of organizational competitiveness and draw a general conclusion.

Results. In the framework of this bibliometric analysis there is a need to analyze the number of publications on "Organizational competitiveness" by year and their citation (table 2).

Table 2. Number of publications on "Organizational competitiveness" (Competitiveness of organization) for 2010-2020 (application date 02.10.2020)

\begin{tabular}{cccccccccccc}
\hline Year & $\mathbf{2 0 1 0}$ & $\mathbf{2 0 1 1}$ & $\mathbf{2 0 1 2}$ & $\mathbf{2 0 1 3}$ & $\mathbf{2 0 1 4}$ & $\mathbf{2 0 1 5}$ & $\mathbf{2 0 1 6}$ & $\mathbf{2 0 1 7}$ & $\mathbf{2 0 1 8}$ & $\mathbf{2 0 1 9}$ & $\mathbf{2 0 2 0 +}$ \\
\hline Google Scholar & 5 & 5 & 8 & 10 & 10 & 15 & 18 & 22 & 11 & 16 & 10 \\
Scopus & 6 & 9 & 10 & 8 & 8 & 13 & 11 & 20 & 7 & 6 & 11 \\
Web of Science & 6 & 8 & 8 & 7 & 8 & 15 & 16 & 20 & 17 & 17 & 8 \\
\hline
\end{tabular}

Sources: developed by the authors based on the Google Scholar, Web of Science and Scopus data.

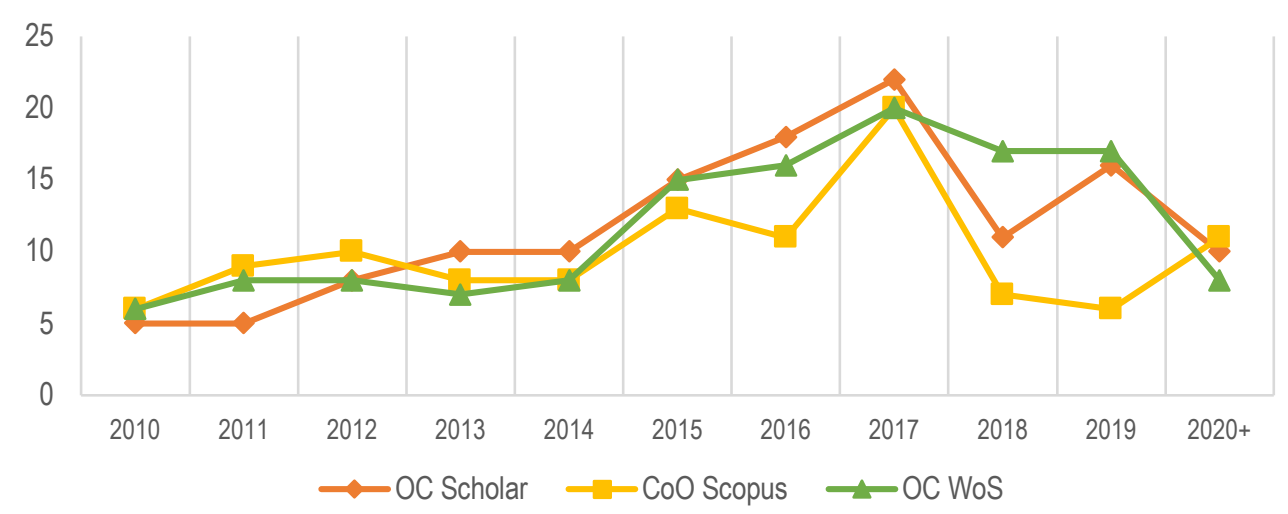

Figure 2. Graphic presentation of publishing activity on "Organizational competitiveness" (Competitiveness of organization) in 2010-2020

Sources: developed by the authors based on the Google Scholar (OC Scholar), Web of Science (OC WoS), and Scopus data (CoO Scopus).

Citations statistics of publications in the databases Google Scholar, Web of Science, and Scopus by key terms "Organizational competitiveness" (Competitiveness of organization) are shown in fig. 3. 


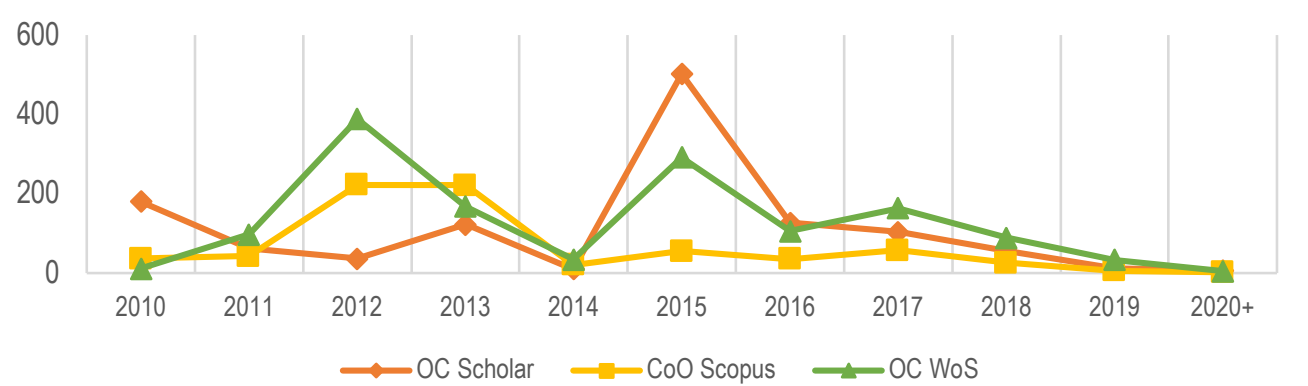

Figure 3. Graphic representation of citations on the topic "Organizational competitiveness" (Competitiveness of organization) in 2010-2020

Sources: developed by the authors based on the Google Scholar (OC Scholar), Web of Science (OC WoS), and Scopus data (CoO Scopus).

These graphs show that the number of publications by year in some way depends on citations. A significant increase in the value of publications with key terms "Organizational competitiveness" leads to a rise in publications on these topics, but with an interval of 2 years. The nature of this dependence must be investigated in further scientific work. At the beginning of our study, the key concept of "Organizational competitiveness" is investigated. Therefore, the total number of publications that include this concept in its title or have such a meaningful component was identified. The period of publications is limited to 20102020. Harzing's Publish or Perish was used to perform this analysis. This software product is publicly available to help scholars around the world to find and shape literature on specific grounds.

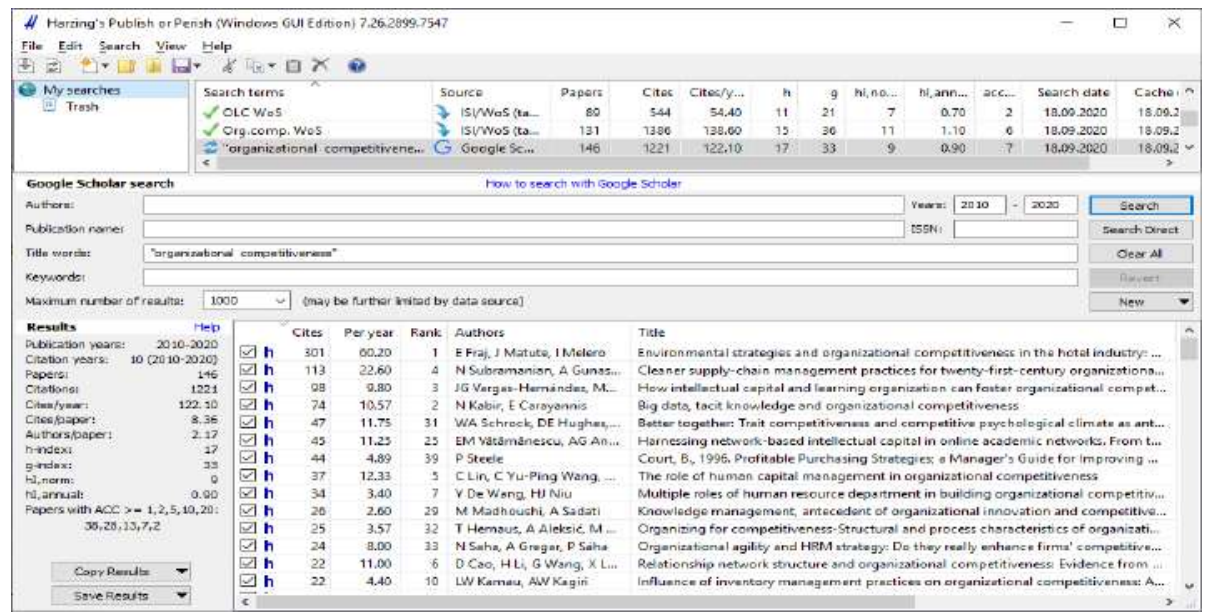

Figure 4. The process of searching for literature sources on the key concept of "Organizational competitiveness" in the Google Scholar database

Sources: Publish or Perish application interface in the process of searching for publications in the Google Scholar database (access date 29.09.2020)

After forming a list of sources, as the main method of data analysis, the program "VOSviewer" was used. The validity and usefulness of this program were performed in earlier studies (Van Eck et al., 2010a). 
This software product is free of charge and allows clustering and network analysis of bibliometric information. The fields "title" and "abstract" were selected as those where the terms will be visible. Also, when forming a bibliometric map, the binary method of calculation was used. Thus, keywords formed thematic clusters. On the "bibliometric maps" presented below, the clusters are marked in different colors, the size of each keyword is determined by the indicator "total link strength", i.e. the strength of the link of this keyword with all others, and the lines reflect the links between two separate keywords (Van Eck et al., 2010b).

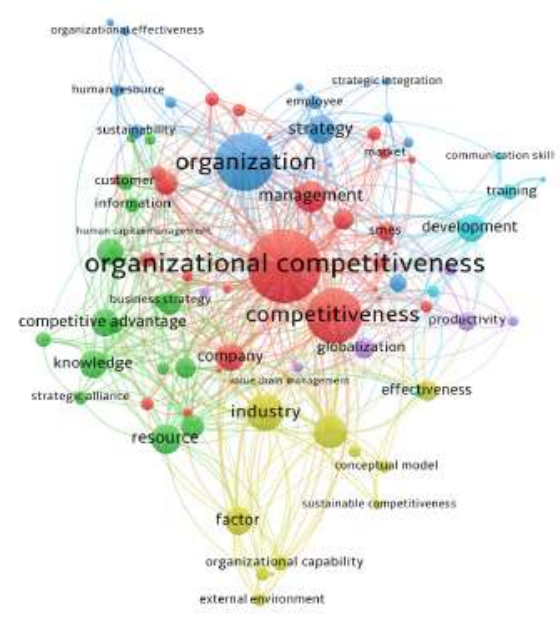

Figure 5. Bibliometric map of publications on the key term "Organizational competitiveness" for 2010-2020 (based on information taken from the Google Scholar database)

Sources: developed by the authors using VOSviewer software tools based on the Google Scholar data.

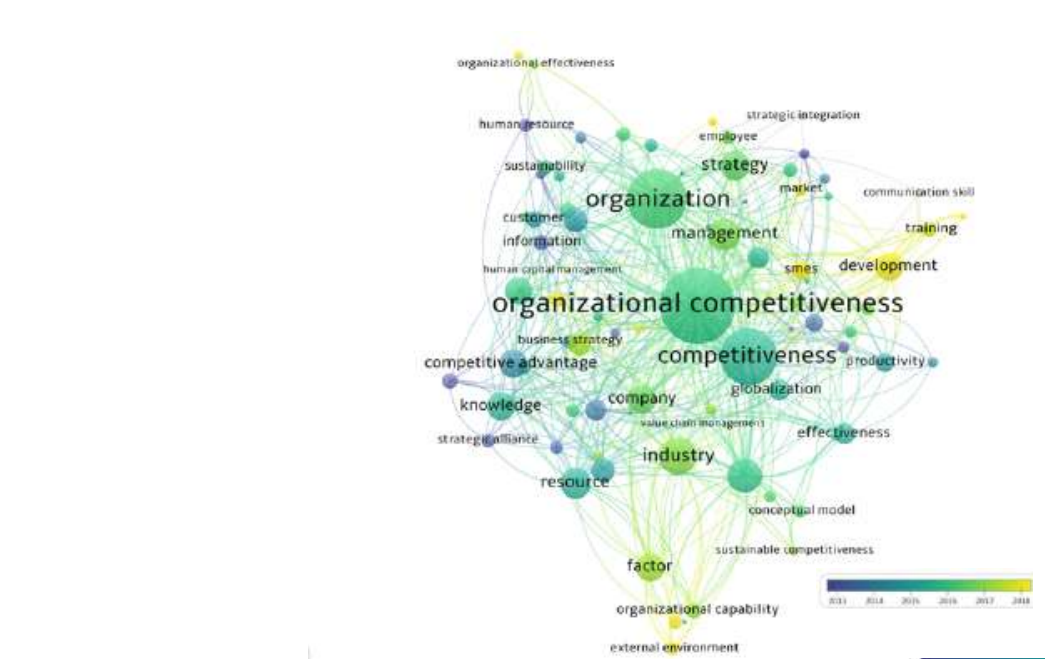

Figure 6. Bibliometric map of publications on the key term "Organizational competitiveness" in the period 2010-2020 (clustering by years)

Sources: developed by the authors using VOSviewer software tools based on the Google Scholar data 
The total array of publications with the key term "Organizational competitiveness" in the Google Scholar database is 146 titles with the number of citations 1221. According to the bibliometric map of publications were formed 6 clusters with a total of 84 concepts.

Table 3. Distribution of concepts by clusters for the key term "Organizational Competitiveness" in the Google Scholar database in the period 2010-2020

\begin{tabular}{|c|c|}
\hline Cluster & Components \\
\hline $\begin{array}{l}\text { Cluster } 1 \\
\text { (red) }\end{array}$ & $\begin{array}{l}\text { advantage, company, competitive environment, competitiveness, effective talent management, } \\
\text { efficiency, empirical evidence, employees professional development, evolution, human capital } \\
\text { management, improvement, information technology, interoperability, inventory management } \\
\text { practice, management, market, market orientation, marketing strategy, organizational } \\
\text { competitiveness, organizational culture, organizational innovation, organizational performance, } \\
\text { retail marketing strategy, small enterprise, SMEs, social asset, strategic planning, supply chain } \\
\text { management, technology, value chain management. }\end{array}$ \\
\hline $\begin{array}{c}\text { Cluster } 2 \\
\text { (green) }\end{array}$ & $\begin{array}{l}\text { business strategy, competitive advantage, competitive edge, competitor, culture, customer, firm, } \\
\text { information, intellectual capital, knowledge, knowledge management, opportunity, organizational } \\
\text { competitiveness factor, resource, strategic alliance, value }\end{array}$ \\
\hline $\begin{array}{l}\text { Cluster } 3 \\
\text { (blue) }\end{array}$ & $\begin{array}{l}\text { benchmarking, competition, dynamic business environment, effective management, empirical } \\
\text { investigation, employee, employer branding, human resource, organization, organizational design, } \\
\text { organizational effectiveness, strategic integration, strategy, strong competition, sustainability }\end{array}$ \\
\hline $\begin{array}{c}\text { Cluster } 4 \\
\text { (yellow) }\end{array}$ & $\begin{array}{l}\text { competency, conceptual model, effectiveness, external environment, factor, industry, innovation, } \\
\text { organizational capability, organizational climate, proactive environmental strategy, sustainable } \\
\text { competitiveness }\end{array}$ \\
\hline $\begin{array}{l}\text { Cluster } 5 \\
\text { (purple) }\end{array}$ & $\begin{array}{l}\text { globalization, internal communication, organizational competitiveness perspective, productivity, } \\
\text { quality, strategic management }\end{array}$ \\
\hline $\begin{array}{l}\text { Cluster } 6 \\
\text { (turquoise) }\end{array}$ & communication skill, development, human capital, investment, reward system, training \\
\hline
\end{tabular}

Clusters reflect the trend towards expanding the scope of interrelated terms, and they also show how these terms correlate with each other. Table 3 shows the affiliation of cluster groups to different scientific approaches to determining organizational competitiveness and its components:

1. Cluster 1 (red) is the largest cluster that combines several approaches. The evolutionary approach involves the development and improvement of small and medium-sized organizations using information technology and organizational innovation. The marketing approach is formed due to the market orientation and market positioning of the organization using the strategy of retail sales in the market. The first cluster can also include a competitive approach that reflects the effective functioning of the organization in a competitive environment.

2. Cluster 2 (green) includes concepts that form a block of competitive advantages of the organization, including such factors of organizational competitiveness as culture, knowledge, and intellectual capital.

3. Cluster 3 (blue) is responsible for assessing organizational performance and benchmarking.

4. Cluster 4 (yellow) reflects the conceptual apparatus of factor analysis of the industry and the development of organizational capabilities.

5. Cluster 5 (purple) identifies problems of ensuring the high quality and productivity of the organization in the context of globalization.

6. Cluster 6 (turquoise) forms the concepts that characterize the training of staff and its development, the system of motivation for work through rewards. 
By analogy, were formed bibliometric maps of publications on the key term "Organizational Competitiveness" for 2010-2020, based on information taken from the databases Web of Science and Scopus.

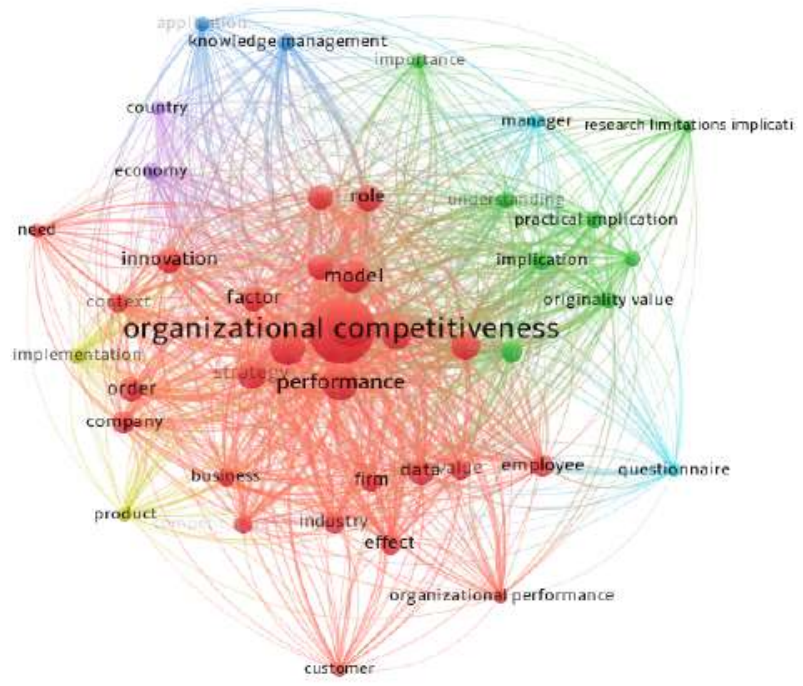

Figure 7. Visualization map of publications on the key term "Organizational competitiveness" for 2010-2020 from Web of Science database

Sources: developed by the authors using VOSviewer software tools based on the Web of Science data

The total array of publications for this key term in the Web of Science database is 131 titles with citations 1386 . The number of concepts for clustering -43 . The total number of links -858 , the indicator "Total links strength" is 4674. To form a bibliometric map of publications, the key term "Organizational Competitiveness" in the Scopus database was replaced by its synonymous expression "Competitiveness of Organization", i.e., the first term produced too small a sample of publications for representative analysis.

The total array of publications for this key term in the Scopus database is 109 titles with the number of citations 724 . The number of concepts for clustering -25 .

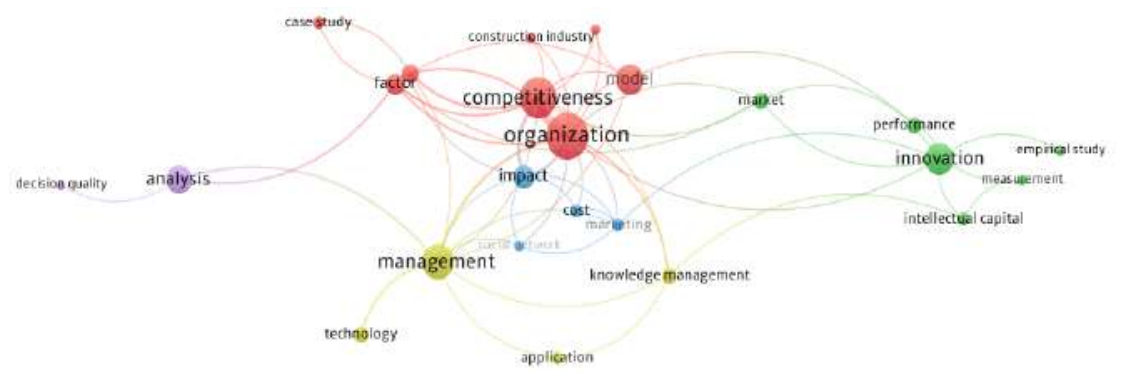

Figure 8. Visualization map of publications on the key term "Competitiveness of Organization" for 2010-2020

Sources: developed by the authors using VOSviewer software tools based on the Scopus data. 
Based on the results of bibliometric maps formation, a consolidated table of key terms by clusters for the three studied scientometric databases was formed. This table includes the concepts that have more significant "weight" among others in their clusters.

Table 3. Comparison of concepts by clusters by key terms "Organizational competitiveness" (Competitiveness of Organization) by three databases in the period 2010-2020.

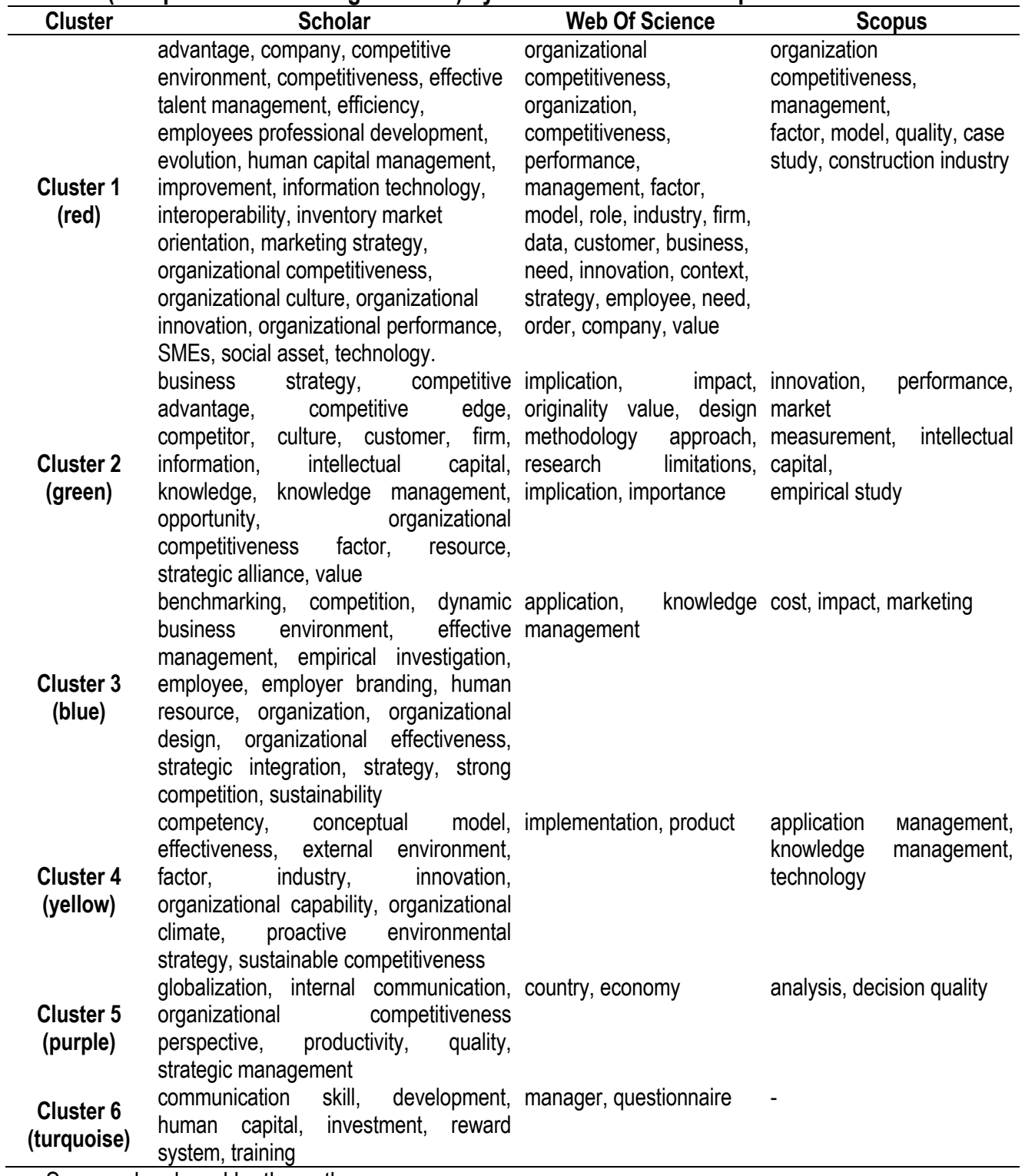

Source: developed by the authors. 
The cluster groups in the Web of Science database affiliation to different scientific approaches to determining organizational competitiveness and its components:

1. Cluster 1 (red) - the competitive approach aims at the survival and successful functioning of the organization in the market, taking into account endogenous (structure, model of organization, innovation, staff, strategy, values) and exogenous (consumers, industry, customer needs, competitors).

2. Cluster 2 (green) - methodological project approach, which includes the limitations of the project, its importance, potential impact, original value, and possible consequences of implementation.

3. Cluster 3 (blue) - formation of a knowledge management mechanism and its application in the process of production and implementation.

4. Cluster 4 (yellow) - reflection the technology of production and sale of products/services.

5. Cluster 5 (purple) - the impact of external macroeconomic factors on the competitiveness of the organization.

6. Cluster 6 (turquoise) - determine staff satisfaction with their jobs and job management via questionnaires.

Similarly, scientific approaches to clusters based on the Scopus database were developed:

1. Cluster 1 (red). Factor approach - the influence of factors and models of development on the level of organizational competitiveness.

2. Cluster 2 (green). Innovation-intellectual approach, which is expressed in the quantitative calculation of the impact of innovation and intellectual capital on the overall level of organizational competitiveness.

3. Cluster 3 (blue). Marketing-cost approach - the impact of marketing costs is directly proportional to the level of organizational competitiveness.

4. Cluster 4 (yellow). Technological approach - is formed to promote the technological development of the organization and quality knowledge management.

5. Cluster 5 (purple). Analytical approach - is expressed in the analysis of the quality of management decisions made to increase the level of organizational competitiveness.

Based on the above proposals and hypotheses regarding the distribution of cluster approaches consolidated table was formed by three scientometric databases (Table 4).

Table 4. Consolidated table of hypothetically formed theoretical and methodological approaches to the formation of cluster groups under the key term "Organizational Competitiveness"

\begin{tabular}{|c|c|c|c|}
\hline Cluster & Scholar & Web of Science & Scopus \\
\hline $\begin{array}{l}\text { Cluster } 1 \\
\text { (red) }\end{array}$ & $\begin{array}{l}\text { Evolutionary approach } \\
\text { Market approach } \\
\text { Competitive approach }\end{array}$ & $\begin{array}{l}\text { Market approach } \\
\text { Factor approach }\end{array}$ & Factor approach \\
\hline $\begin{array}{l}\text { Cluster } 2 \\
\text { (green) }\end{array}$ & $\begin{array}{c}\text { Factor approach } \\
\text { Knowledge management } \\
\text { approach }\end{array}$ & Project approach & $\begin{array}{c}\text { Innovation-intellectual } \\
\text { approach }\end{array}$ \\
\hline $\begin{array}{c}\text { Cluster } 3 \\
\text { (blue) }\end{array}$ & Benchmarking approach & $\begin{array}{c}\text { Knowledge management } \\
\text { approach }\end{array}$ & Marketing-cost approach \\
\hline $\begin{array}{c}\text { Cluster } 4 \\
\text { (yellow) }\end{array}$ & Analytical approach & $\begin{array}{l}\text { Production (technological) and } \\
\text { sales approach }\end{array}$ & Technological approach \\
\hline $\begin{array}{l}\text { Cluster } 5 \\
\text { (purple) }\end{array}$ & $\begin{array}{c}\text { Globalizational } \\
\text { (macroeconomical) approach }\end{array}$ & Macroeconomical approach & Analytical approach \\
\hline $\begin{array}{c}\text { Cluster } 6 \\
\text { (turquoise) }\end{array}$ & $\begin{array}{c}\text { Motivational-career (staff) } \\
\text { approach }\end{array}$ & Analytical approach & - \\
\hline
\end{tabular}

Source: developed by the authors. 
The formed table allows to assume what approaches to definition of cluster groups can be used. According to the definition of the proposed theoretical approaches, it is possible to find additional links with endogenous and exogenous factors of organizational competitiveness. A hypothetically formed list of approaches to the formation of cluster groups is proposed for further use in defining related concepts of the key term "Organizational Competitiveness". The dependence of the number of formed approaches is directly proportional to the number of concepts to clustering. Due to a large number of clusters of concepts, more links between related scientific fields can be considered.

Conclusions. Summarizing all the research findings showed that organizational competitiveness is the ability to use the internal potential of the organization, forming and developing competitive advantages in accordance with the requirements and conditions of the micro and macroenvironment. The main outcomes of this bibliometric analysis are a method developed for cluster formation of key term evolution, explanation of the dependencies in the distribution of the clusters of relevant terms in the field of research, their links with each other, the degree of belonging to a particular factor of organizational competitiveness. It was revealed peculiarities of the cluster distribution of interconnected concepts of the key term "Organizational competitiveness", such as their belonging to endogenous and exogenous environmental factors, which give a new understanding of the pattern of grouping terms relevant to the field.

Author Contributions: conceptualization, S.K and I.H; methodology, S.K; validation, S.K and D.Y; formal analysis and investigation, S.K and I.H; resources and data curation, D.Y; writing-original draft preparation, S.K.; visualization, S.K; writing-review, editing, and supervision, I.H; project administration, D.Y. All authors have read and approved the final manuscript.

\section{References}

Ageron, B., Gunasekaran, A., Spalanzani, A., (2012). Sustainable supply management: An empirical study. International Journal of Production Economics, 140(1), 168-182, [CrossRef].

Bai, C., Sarkis, J. (2013). A grey-based DEMATEL model for evaluating business process management critical success factors. International Journal of Production Economics, 146(1), 281-292. [CrossRef]

Delios, A. (2010). How Can Organizations Be Competitive but Dare to Care?. Academy of Management Perspectives, 24, 2536, [CrossRef]

Fraj, E., Matute, J. and Melero, I. (2015). Environmental strategies and organizational competitiveness in the hotel industry: The role of learning and innovation as determinants of environmental success. Tourism Management, 46(C), 30-42. [CrossRef]

Garrigós-Simón, F.J., Alcamí, R.L., \& Ribera, T. (2012). Social networks and Web 3.0: their impact on the management and marketing of organizations. Management Decision, 50, 1880-1890. [CrossRef]

Gunasekaran, A., Ngai E. (2012). The future of operations management: An outlook and analysis. International Journal of Production Economics, 135(2), 687-701, [CrossRef]

Kabir, N., Carayannis, E. (2013). Big data, tacit knowledge and organizational competitiveness. Knowledge Management and Organisational Learning: ICICKM. [CrossRef]

Kotenko, S., Kobushko, la., Heiets, I., \& Rusanov, O. (2021a). KPI Model Impact on Employee Motivation and Competitiveness of Private Healthcare Facilities. Health Economics and Management Review, 2, 31-42. [CrossRef]

Kotenko, S., Shvindina, H. (2018). Problems of assessing the competitiveness of enterprises as an indicator of strategic development. Problems of Economics, 3(37), 104-112. [Link]

Kotenko, S., Shvindina, H. (2020). Reengineering of business processes as a direction of increasing the competitiveness of industrial enterprises. Visnyk of Sumy State University. Economics series. 2, 174-180. [CrossRef]

Kotenko, S., Shvindina, H., \& Heiets I. (2021b). The impact of migration on the competitiveness of the region and industry development. E3S Web of Conferences, 307, 02003 [CrossRef]

Noruzi, M., \& Vargas-Hérnandez, J. (2010). How Intellectual Capital and Learning Organization Can Foster Organizational Competitiveness. International Journal of Biometrics, 5, 183. DOI: [CrossRef]

Shvindina, H. (2020) Economic Competitiveness: An Overview of Multilevel Concept. In: Leal Filho W., Azul A.M., Brandli L., özuyar PG, Wall T. (eds) Responsible Consumption and Production. Encyclopedia of the UN Sustainable Development Goals. Springer, Cham. [CrossRef] 
Subramanian, N., Gunasekaran, A. (2015). Cleaner supply-chain management practices for twenty-first-century organizational competitiveness: Practice-performance framework and research propositions. International Journal of Production Economics, 164(C) 216-233. [CrossRef]

Van Eck, N. J. et al. (2010b). A comparison of two techniques for bibliometric mapping: Multidimensional scaling and VOS. Journal of the American Society for Information Science and Technology, 61(12), 2405-2416 (2).

Van Eck, N. J., Waltman, L. (2010a). Software survey: VOSviewer, a computer program for bibliometric mapping. Scientometrics, 84(2), 523-538 (1).

Wong, C., Kee-hung Lai \& Cheng, T. (2011). Value of Information Integration to Supply Chain Management: Roles of Internal and External Contingencies. Journal of Management Information Systems, 28(3), 161-200 [CrossRef]

Wu, C.-Y., Heiets, I., \& Shvindina, H. (2020). Business Model Management of Low-Cost Carriers: in a Search for Impact-Factors of Performance (Case of AirAsia Group Airlines). Marketing and Management of Innovations, 2, 354-367. [CrossRef]

Yazdani, M., Chatterjee, P., Zavadskas, E. K., \& Zolfani, S. H. (2017). Integrated QFD-MCDM framework for green supplier selection. Journal of Cleaner Production, 142, 3728-3740. [CrossRef]

Станіслав Котенко, Сумський державний університет, Україна

Ірина Геєць, Ph.D., RMIT університет, Австралія

Діна Якоут, Ph.D., Приватний інститут маркетингу, Єгипет

Організаційна конкурентоспроможність: систематичний огляд літератури

Одним з основних економічних законів, що відображають закономірності економічних явищ, є закон конкуренції. Згідно з ним, в умовах ринкової економіки успішно діють і розвиваються ті суб'єкти господарювання, які мають певні конкурентні переваги. У рамках конкурентного ринку організації змушені дбати про підвищення власної конкурентоспроможності, формування певних конкурентних переваг у відповідних просторово-часових умовах. Глобалізація та тенденції інтеграції ставлять більш жорсткі та складні вимоги до підприємств, що призводить до посилення конкуренції між ними на національному та міжнародному ринках. Багатофракторна залежність конкурентоспроможності організації дає можливість формувати нові шляхи підвищення його рівня. Ендогенні та екзогенні чинники, своєю чергою, створюють функціональні зв'язки між різними галузями економіки. У статті представлено бібліометричний аналіз поняття "організаційна конкурентоспроможність" з використанням програмного забезпечення для визначення зв'язків між факторами організаційної конкурентоспроможності, їх джерелами та дослідниками. Методи, використані у дослідженні, включають початковий пошук за ключовими словами, аналіз та уточнення даних, а також кластеризацію. Інструмент Harzing's Publish or Perish використовується для початкового пошуку, BibExcel, VOSviewer та MS Excel - для аналізу та уточнення даних. У статті використано дані з трьох найбільших баз даних наукових публікацій: Google Scholar, Web of Science та Scopus. Пошук та порівняння інформації, взятої з кількох джерел, дозволяє провести комплексний аналіз літератури та виявити основні характеристики візуалізаційних карт взаємозв'язків у сформованій вибірці дослідження за відповідними параметрами. У рамках цього дослідження авторами згенеровано та проаналізовано кластерні групи понять, принципи їх групування, визначено наукові підходи до кластеризації ключових термінів у кількох базах даних. Актуальність цього дослідження полягає в його впливі на процес формування понятійних кластерів. За допомогою запропонованих наукових підходів можна пояснити залежності в кластерному розподілі окремих визначень, їх взаємозв'язок, ступінь належності до певного фактора організаційної конкурентоспроможності.

Ключові слова: аналіз, бібліометрія, організаційна конкурентоспроможність, фактори, кластеризація, публікації, візуалізація. 